\title{
Immersive Learning Design (ILD): A New Model to Assure the Quality of Learning through Flipped Classrooms
}

\author{
Hamdy A. Abdelaziz ${ }^{1,2}$ \\ ${ }^{1}$ Arabian Gulf University, Manama, Bahrain \\ ${ }^{2}$ College of Education, Tanta University, Tanta, Egypt \\ Email: hamdyaaa@agu.edu.bh
}

Received 26 September 2014; revised 27 October 2014; accepted 5 November 2014

Copyright (C) 2014 by author and Scientific Research Publishing Inc.

This work is licensed under the Creative Commons Attribution International License (CC BY). http://creativecommons.org/licenses/by/4.0/

(c) (i) Open Access

\section{Abstract}

The objective of this paper was to develop an immersive Web-based learning model to assure the quality of learning through the flipped classrooms. The proposed model was guided theoretically by the flipped classroom as a new Web-based learning trend/system. It was also guided pedagogically by active and reflective learning principles that support transforming of the teaching and learning practices from content engagement to cognitive engagement. The targeted immersive learning model encompasses four reciprocal phases: Pro-act, Act, Reflect, and Re-act (PARR). To validate the suggested model, a convenience sample of graduate students studying an advanced statistics course was selected from the Distance Teaching and Training Program at Arabian Gulf University. After designing and applying this new immersive Web-based learning model (PARR), findings revealed that using the flipped classroom through this immersive Web-based learning model has a statistical and practical impact on developing achievement and self-study skills among graduate students. The contribution of this research is that it qualifies the Web-based instructional practices to shift from content acquisition act to knowledge expression and creation act. In addition, the paper will be of benefit to people looking for pedagogical applications of virtual and blended learning environments for developing multiple ways to express what learners know and be able to do.

\section{Keywords}

Immersive Learning Design, Cognitive Engagement, Flipped Classrooms, Self-Study Skills, Online Pedagogy 


\section{Introduction}

Learning is the driving force for the future. Current learning model is facing a paradigm shift in its content, delivery methods, and assessment techniques. This shift is occurring because of the increasing demand on Information and Communication Technology (ICT) and social media network applications [1]. ICT and social media network are the driving educational means in current age which can be identified as The Third Renaissance Age. Continuous innovations released every year in information and communication technology and social media network represent a double load loop on our current learning and teaching model/s. This shift is pushing us to think about an answer to the following question: How can we shift our learning model from being focused on content engagement to on cognitive engagement to prepare the third renaissance learners' mind?

Third renaissance learners are having collective mind that is diverse, distinct, and dynamic. They need a diverse, distinct, and dynamic learning ecology [2]. The previously mentioned attributes are long-term characteristics of learning models. In such learning ecology, learning is occurring much faster than time. Third renaissance learners are divers in their learning styles and preferences. They need teaching style and curriculum framework and activities that fit with their collective minds and daily habits. In the meantime, third renaissance learning ecology is dynamic, that is it helps in moving creative ideas and solutions between learners regardless of their nationality or even the time zoon they belong to. Dynamic learning is one theme that governs future learners' interactions. It helps in building mind nods that are adaptive and concurrent. It gives learners what they needs of elasticity to direct generating ideas and solutions and share them with others for more meaningful learning. Therefore, future learning models should be diverse, distinct, and dynamic to overcome future learners' mental and social needs. Diverse, distinct, and dynamic learning ecology help promote deep rather than surface learning. Future learning models should also support the shift from content engagement (knowledge transfer) to cognitive engagement (knowledge creation and distribution) [3].

Both self-questioning and self-study skills are reflecting the life-long and self-determined learning skills which have been recognized as one of the most important priorities of the 21st century learning paradigm [4], [5]. The 21st century learning paradigm needs to rethink how we design new teaching and learning models and strategies that can respond to the learning requirements and reflect the characteristics of knowledge and learning which are basically personal, social, distributed, dynamic, and versatile in nature nowadays [6]. The main purpose of this paper is to develop an immersive learning model and validate its impact on developing self-study skills and achievement among a sample of graduate students.

\section{Theoretical Background and Literature Review}

Current Web-enhanced learning models and strategies failed to cope with the fast-paced change and critical challenges of the new knowledge society. To align with this shifts of new knowledge era, [6] suggested the 3P learning model. The 3P learning model consisted of three core elements: Personalization, Participation, and Knowledge-Pull. With the increased dependency on the Web, the Internet and social media networks and educational technology, learning is becoming social by nature. Learning is also becoming personal, self-directed and self-determined matter.

This shift has made most, if not all, of the teaching and learning practices transform from a knowledge-push to a knowledge-pull model. According to [6] in the knowledge-push model, the information flow is guided and directed by the instructor, but in the knowledge-pull model, the learner is the investigator and knowledge builder and maker. Moreover, online and blended education provide learners much more freedom in how and when they interact, and therefore, their ability to organize and regulate their own learning seems to be important [7]. Flipped classroom is one of the most new online teaching shifts that depend on knowledge-pull model. It helps in transforming online learning and teaching from being a top-down (teacher-control) into bottom-up (learnercontrol) process.

\subsection{Flipped Classroom}

Flipped classroom is a new trend of providing and delivering learning through applying ICT. The main premise of this new trend is to share learning responsibility and ownership of learning between learners and instructors. It helps in personalizing learning. "Flipping the classroom establishes a framework that ensures students receive a personalized education tailored to their individual needs and learning styles” ([8] p. 6). Personalized learning 
is a positive goal to reach for each student. It's the gate way to get learners involved in an immersive design process that guarantee deep learning and deep understanding of learning materials.

"Flipped classroom has some similarities with Web-based learning, blended learning, reverse instruction, and 24/7 classroom” ([8] p. 7). It may increase the probability of fixing learning according to learners' level and make learning environment more dynamic, diverse, distinct, and self-determined. Moving from teaching-centered to learner-centered environment is one of the most important conditions to increase learners' motivation especially intrinsic motivation.

Flipped classroom has been adopted and applied in many states to achieve academic goals and overcome the shortage of teachers' performance in some schools districts in the United States [9]. Although the demand for flipped classroom is increasing worldwide, little attention in the literature has been paid to this kind of reversed instruction. Flipped classroom is a relatively new web-based teaching approach that needs well-developed learning strategy in which online learners can immerse and engage themselves cognitively into learning and teaching process based on their level of control and understanding. [10] stated that "the use of virtual world, with text-based, voice-based and a feeling of 'presence' is allowing for more complex social interactions and designed learning experiences and role plays, as well as encouraging learner empowerment through increased interactivity” (p. 69).

Moving Web and online instructional practices from being just teaching environment into personal learning environment (PLE), needs an immersive design learning model to help online and blended learners to be selfregulated, self-directed and self-determined learners.

\subsection{Theoretical and Pedagogical Foundations of Immersive Learning}

The author believes that the immersive learning concept supports self-regulated, self-determined, self-controlled, informal and life-long learning. It translates the principles of learning that have been raised and adopted by past and recent learning theories. For example, the connectivist, as a recent learning perspective, presents learning as a connection and network-forming process [11]. The theory of connectivism supports learning that can reside outside the learner through a learner-oriented network. Personal learning network (PLN) is also a theme of connectivism theory. It helps online learners to aggregate and integrate knowledge through encompassing tacit knowledge nodes and explicit knowledge nodes [12].

Based on this perspective, we can say that the new learning model, the immersive learning model, is a network of cognitive engagement and practice and is supported by personal learning environments. In such personal learning environments, learners will be able to: 1) set their own learning goals, 2) manage their learning levels and times, 3) interact with other learners based on their own felt needs, and 4) be self-determined and self-directed learner.

Immersive learning design is also supported by the learning principles of constructivism theory. According to constructivist model, learner is not a passive recipient but rather the center of instruction. The learners actively participate in their learning process by inquiry and discovery, with the instructor as the facilitator and mediator of the learning process [13]. What is significant here is that knowledge is not something to be acquired. Rather, it is constructed by exposing it to personal interpretations that are necessary for meaning making. Immersive learning is also guided by experiential and active learning theory. According to [14], experiential learning is an active learning framework that encompasses the following principles: 1) the do principle, 2) the observe Principle, 3) the reflect principle, and 4) the plan principle.

Constructivists also believe that meaning can be communicated through tools, culture and society. When we interact with others in communities of inquiry, our knowledge and beliefs are affected by knowledge and values of the surrounding community. This constitutes what can be termed "Collective Memory". Participation in collective memory makes societies dynamic [15]. The quantity and quality of collective memory vary according to the quantity and quality of individuals' knowledge

McCarthy's 4MAT [16] model is similar with Kolb's experiential model. The 4MAT model is mainly reflecting the process for delivering online and blended instruction from teachers' perspective. The 4MAT model is consisted of four stages encompassing eight main learning tasks. According to [16], the 4MAT model has four main stages: 1) engaging learners, 2) inform learners, 3) providing opportunity to try it out, and 4) providing opportunity to creatively integrate new materials. These four stages have eight integrated tasks that instructors should take into consideration while delivering teaching; and they are: connect, attend, imagine, inform, practice, 
extend, refine, and perform.

Doolittle [17] also confirms the importance of active learning environment for online students. He recommended that in active learning environment, learning involves active cognitive processing. In addition, learning should involve social negotiation and mediation. Active online learning environment encourages student to become self-regulator, self-mediated, and self-aware.

Immersive learning has its fundamental roots from cognitive theory too. The cognitive theory views learning as involving the acquisition or reorganization of the cognitive and mental structures created by human minds to process and store information. According to cognitive perspective, mental process transform information received into cognition and skills within individual memory. The impact of cognitive science on instructional design is evidenced by the use of metaphors, chunking content and knowledge into meaningful parts, advance organizer, and the careful organization of instructional materials from simple to complex and from general to specific [18].

The immersive learning design model is also guided by cognitive apprenticeship as a pedagogical approach to enhance cognitive engagement among learners. Collins [19] defined the value of the cognitive apprenticeship through a set of features to assist the design, implementation, and evaluation of technology integration in learning environments. These features contain, but are not limited to: situated learning, modeling and explaining, coaching, articulation, and exploration.

\subsection{Cognitive Engagement}

In their study, [20] noted that researchers have identified at least three types of engagement: behavioral, emotional and cognitive engagement. [21] have also reported four kinds of engagement: procedural, conceptual, consequential, and critical engagement. In online, blended and/or e-learning settings, engagement refers to the quality and quantity of effort learners make to perform well and achieve desired intended learning outcomes [22]. The concept of engagement is attracting increasing attention nowadays specially with the increased rate of adopting and applying social media network for pedagogical purposes. Cognitive engagement and the quality of technology have been found to be motivational factors in e-learning environments [20]. [23] also stated that "engagement includes on-task behavior... when engagement is characterized by full range of on-task behavior, positive emotion, invested cognition, and personal voice, it functions as the engine for learning and development" (p. 227). When learners are engaged in deep inquiry processing during an academic task, they demonstrate high level of cognitive and metacognitive engagement [24].

Formal and informal learning always begins with student's engagement, which in turn leads to knowledge and understanding. Once a learner understands, he or she becomes capable of performance or action [25]. In this regard, [26] presents a six-stage learning process for cognitive engagement: engagement and motivation, knowledge and understanding, performance and action, reflection and critique, judgment and design, and commitment and identity. Cognitive engagement is the pathway to improve learners' curiosity. Cognitive engagement was a function of the learning event. In their study, [27] concluded that students' cognitive engagement significantly increased as function of problem-based learning classroom.

\section{Immersive Learning Design}

\subsection{Definition of Immersive Learning}

[10] define immersive learning as a framework that encompasses of four dimensional: learner specifics, pedagogy, representation, and context. This definition is theoretically and practically differing than the definition of immersive learning design in current research. The researcher believes that immersive learning starts from the individual learner and focuses on cognitive engagement network as a mind tool to move forward and backward through four reciprocal phases/techniques of engagements: Pro-acting engagement, acting engagement, reflecting engagement, and re-acting engagement. Immersive learning is self-organized, self-determined, decentralized, opened, and emerged and generative learning. The proposed immersive learning design model in current research is mainly reflecting the processes and techniques that online and blended learners are doing/should do to learn and understand course materials via flipped classroom. Figure 1 summarizes these four phases/techniques and its related sub-techniques. 


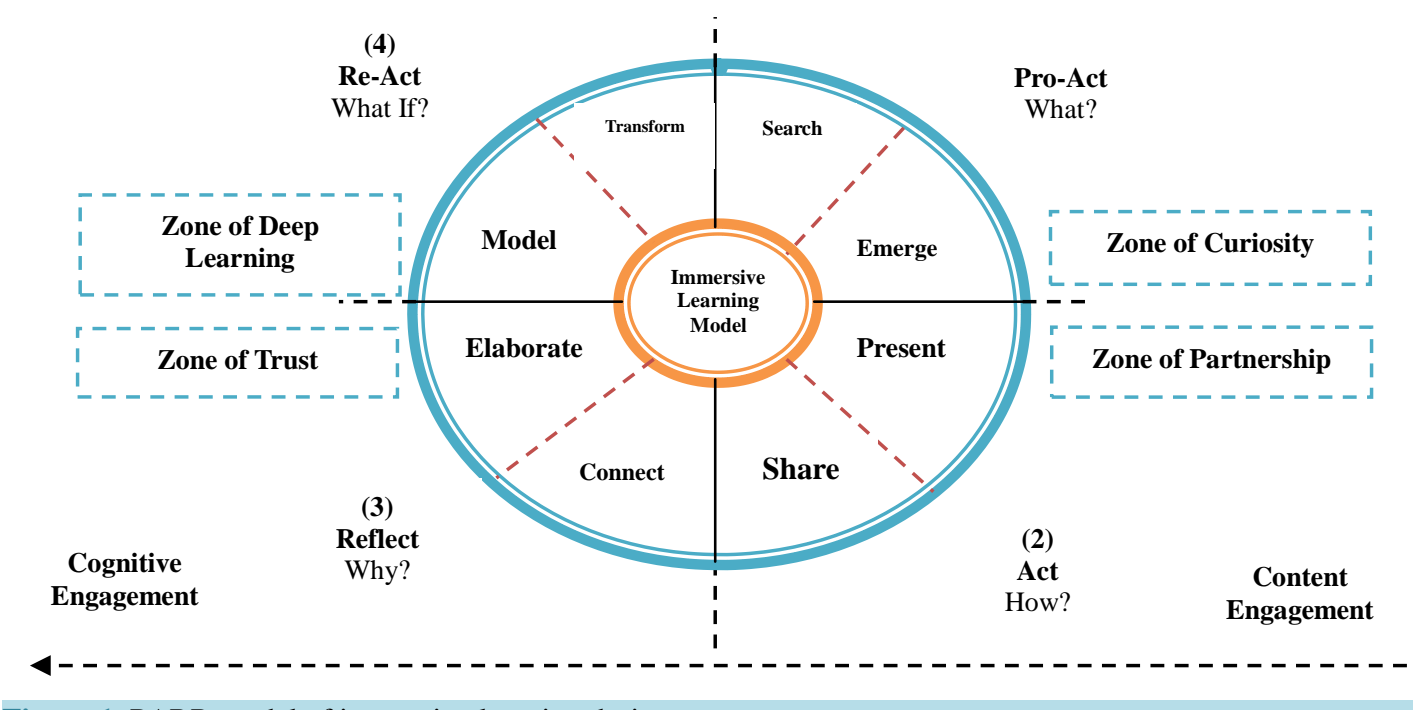

Figure 1. PARR model of immersive learning design.

\subsection{Immersive Learning Design Phases and Techniques}

Immersive learning model is a generative model in which learner generates perception and meaning through a process of pro-acting, acting, reflecting, and re-acting. This immersive learning model could work well with online, blended, and distance learners. Based on the suggested immersive learning design phases and its related sub-techniques mentioned in Figure 1, the researcher presents the definitions, processes and expected outcomes for each phase in the following.

\subsubsection{Pro-Acting Engagement}

In pro-acting engagement, learners are building what the author calls "Zone of Curiosity". In online and distance learning environments, the curiosity leads to interest and engagement [28]. In order to learn according to this immersive learning model, learner should start pro-acting by searching, emerging, and aggregating online and Web-based instructor-uploaded and learner-selected online materials and resources. The purpose of this technique is to stimulate students' mind and emotion to be self-regulated and self-determined learner. It pushes challenges in the front of students. Student should ask himself questions to make sure he/she understands the content and course materials. Pro-acting technique is guided by inquiry-based learning in which learner is interacting with course materials through a line of reading and taking personal notes. Reading and interacting with e-content and text books in pro-active phase considers as an advanced mental organizer in which online learners is establishing prior mental structure, image and beliefs of course materials.

The expected outcome of pro-active engagement technique is a personal knowledge network which can take a form of initial learner's portfolio. This initial portfolio contains the main concepts and information that reflect learners' pre-understanding of course materials. It should also contain the most difficult questions and/or issues raised from studying course/unit materials at distance. These self-generated questions and issues will be presented and discussed in the next face-to-face class session. This phase of content engagement reflects student's self-study skills. It's also the first step to measure the student's self-understanding of course-related materials submitted by course instructor and extra materials collected by student himself. Proactive engagement with online materials is the learners' mental assets. The meta-expected outcome of pro-acting stage is an answer to what question. In pro-acting-engagement stage, learner is information seeker and navigator and teacher is information facilitator and distributor.

\subsubsection{Acting Engagement}

In acting engagement, learners are building what the author calls "Zone of Partnership”. Acting engagement is the personal roadmap to build meaningful understanding of course materials.

In this stage, each student is presenting his/her initial understanding collected from the pro-acting stage. In acting engagement stage, each student shares his work that may take a form of questions and/or pre-mind map 
regarding course materials. In this stage, students are building what the author calls "learning partnership”. In learning partnership, a shard responsibility regarding understanding course new concepts and principles is establishing. Partnership learning looks like collaborative learning in which students are sharing what their mind brought from the first stage, pro-acting. Sharing concepts and ideas between classmates and instructor is one important factor to increase self-esteem and confidence among learners. It's also an essential factor to increase students' self-efficacy.

The researcher believes that the most expected outcomes for acting engagement phase in the future is that it will increase learners' self-efficacy and self-questioning skills. In their research, [29] found that learners with higher computer self-efficacy tended to spend more time using online and blended learning technology and were therefore more engaged in the learning situations. Active engagement has several learning layers, these are: acquire the information or ideas, from reading or e-lectures, then to have an experience, such as learning seminar and oral presentation activities [30]. The active flipped classroom facilitates personal involvement with materials and encourages students to discuss what they get, understand, and feel.

In addition to presenting and sharing what they collect in the first stage, pro-acting, learners are expecting to have signposting ideas that reflect their own and others' understanding about course materials. The expecting outcome of active engagement is an answer to how question.

In active engagement, classroom interaction is an important action to prevent learner of constructing wrong knowledge. In flipped classrooms, learners might construct wrong knowledge because they have almost unlimited freedom of choice to select what to and how to study from among available resources and online materials [25]. In acting-engagement stage, learner is knowledge generator and instructor is knowledge mediator.

\subsubsection{Reflecting Engagement}

In reflecting engagement, learners are building what the author calls "Zone of Trust". In this stage, online learners are practicing a sense-making process in which they assess the value of their own perspectives and other learners' perspectives. This is the stage of examining and validating learners' capacity to know and do. It's a meta-cognition process that enhances where students know what they know. They revisit and revise what they have done in the acting engagement stage based on external and internal feedback. In reflecting engagement, intrinsic feedback is an integral part of supporting learners' reflection.

Intrinsic feedback is a kind of self-negotiation between old and new information and knowledge learnt from learning and teaching context. At this stage, learners recognize that knowledge is constructed through the contributions of many classmates but still need personal responsibility for seeking the view that explains the available evidence [31]. Reflection has an impact on building self-questioning skills. According to [32], reflection is facilitating both diagnosis of core strengths and weaknesses, and the acquisition of a questioning approach. Reflection is a mental process that integrates critical thinking about personal experience and demonstrates learning that can be taken backward and forward [30]. By engaging in reflection-engagement learning, online learners are practicing self-evaluation and self-assessment and acquiring the habit of reflection-on-action.

It could be noticed that engaging in reflection is a vital part of immersive learning design model for online and reversed learning classes. It's a feeding forward building mental models and strong nodes. The outcomes of this stage are very important to re-acting engagement, next stage. The meta-expected outcome of reflecting-engagement stage is an answer to why question. In reflecting engagement stage, learner is cognition builder and creator and instructor is cognition activator and cognition coach.

\subsubsection{Re-Act Engagement}

In re-act engagement, learners are building what the author calls "Zone of Deep Learning". This is the stage of epistemological development and beliefs empowerment. In this stage, online learners will develop personal mental models. These mental models are reflecting and supporting deeper engagement in learning context. Learners will have greater intellectual flexibility in which they will be able to transform what is learnt to other learning content and context. By exercising mental modeling, a learner develops personal commitment. In commitment, learner becomes capable of professionalizing his understanding and values. Internalizing those attributes and making them integral part of his or her identity. These commitments, in turn, make new engagements flexible and even mental nods for further action. In this stage, learner establishes a personal learning network that composed of personal mind nodes that could be used to transform new learnt concepts, principles and ideas into other contexts or learning situations whether or not they are similar with current situations or contexts. 
By the end of re-acting stage, learner is exercising what is called "self-authorship". According to [33], "selfauthorship is simultaneously and ability to build and construct knowledge in a contextual world, an ability to construct an internal identity separate from external influences, and an ability to engage in relationship without losing one's internal identity” (p. 12). Self-authorship is reflecting learners' identity and personal voices and ownership of learning. Learner is moving from content achiever to cognition provider. The meta-expected outcome of re-acting-engagement stage is an answer to what if question. In re-acting engagement stage, learner is cognition distributor and manager and instructor is cognition maintainer.

\section{Significance of the Study}

The present study derives its significance from the fact that it is the first attempt, to the best of the researcher's knowledge, to develop a dynamic and constructive immersive learning model to learn from/with virtual and e-learning in all programs including e-courses. More specifically, the study is expected to:

1) urge specialists to question the traditional learning models and strategies in the light of the proposed model;

2) guide designers and developers of the electronic content in the selection and construction instructional tools that suit various flipped classrooms;

3) help staff members using flipped classroom to evaluate depth of meaning and generation of retainable knowledge and cognition;

4) help personnel in charge with electronic or virtual programs to select evaluation techniques that enhance quality of instruction and learning;

5) shift attention from quality of technology to quality of pedagogy to foster meaningful learning;

6) initiate a trend to develop smart and flexible learning models that suit various Web-based learning situations;

7) direct attention to conducting theoretical and developmental studies in addition to experimental studies to develop self-questioning and self-study skills; and

8) provide those in charge with setting standards for virtual and e-learning with evaluation levels and frameworks that suit change in learners' cognitive engagement.

\section{Hypotheses}

The researcher tested the following two hypotheses:

1) The presentation of the proposed immersive learning model would not lead to significant differences between the performance of the experimental group and the control group on self-study skills.

2) The presentation of the proposed immersive learning model would not lead to significant differences between the performance of the experimental group and the control group on the achievement test.

\section{Methodology}

\subsection{Method and Procedures}

To validate the proposed model of immersive learning design, the researcher exposed it to experimentation using the quasi-experimental method. The model was applied to a sample of the students in the distance teaching and training program at the Arabian Gulf University. What follows is a description of the procedures used to validate the proposed model.

\subsection{Sample}

The sample consisted of 24 male and female students enrolled in the distance teaching and training program at the Arabian Gulf University. The sample was intentionally selected and stratified into two groups: a control group and an experimental group. The control group consisted of 10 students enrolled in the program in 2010/11. The experimental group consisted of 14 students enrolled in the program in 2011/12. Blended learning approach was applied on the control group; whereas, flipped classroom approach was applied on the experimental group.

\subsection{Experimentation Setting}

The targeted model was applied to students in the distance teaching and training program in the Arabian Gulf 
University. This program grants the Certificate of Higher Studies Diploma and Master Degree in distance teaching and training. This program was developed in collaboration with Sunderland University, UK. There is no similar program in all Arabic countries. It offers courses in the form of instructional modules using the blended learning strategy. The proposed model was applied to students studying analysis quantitative data course. This course is 2 credit hours, and delivered in Spring semester each year. Its content focuses on advanced statistical techniques for quantitative data analysis such as: testing statistical hypotheses, between groups comparison tests, analysis of variance and covariance, and non-parametric data analysis techniques. It is an obligatory course for Master Degree students.

\subsection{The Experimental Design}

The control group post-test only experimental design was utilized in the study. The instruments, self-study skills scale and achievement test, were applied to the experimental and the control group as post-test.

\subsection{Procedures}

To put the proposed immersive learning design model into action, the researcher designed and developed an instructional strategy to expose this model to the experimental group. Table 1 summarizes the developed instructional strategy that was applied to validate the proposed model in this study.

\subsection{Instruments}

The dependent variables in this study were measured by self-study skills scale and achievement test. What follows is a description of the procedures used to develop and validate those instruments.

Table 1. The instructional strategy used to validate the proposed model of immersive learning design.

\begin{tabular}{|c|c|c|c|c|c|c|}
\hline $\begin{array}{l}\text { PARR } \\
\text { stages }\end{array}$ & $\begin{array}{c}\text { Learning } \\
\text { techniques }\end{array}$ & $\begin{array}{c}\text { Learner's } \\
\text { roles }\end{array}$ & $\begin{array}{l}\text { Teacher's } \\
\text { roles }\end{array}$ & Teaching activities & Learning activities & Types of interaction \\
\hline $\begin{array}{l}\text { Pro-acting- } \\
\text { engagement }\end{array}$ & $\begin{array}{l}\text { - Search } \\
\text { - Emerge }\end{array}$ & $\begin{array}{c}\text { Information } \\
\text { seeker and } \\
\text { navigator }\end{array}$ & $\begin{array}{l}\text { Information } \\
\text { distributor and } \\
\text { facilitator }\end{array}$ & $\begin{array}{l}\text { e-lectures, e-stories, } \\
\text { audio and visual aids and } \\
\text { demos based teaching, } \\
\text { distant teaching and } \\
\text { learning conversation, } \\
\text { e-tutorials }\end{array}$ & $\begin{array}{l}\text { Out-of-class activities: Observation, } \\
\text { watching, reading, summarizing, } \\
\text { note-taking, } \\
\text { mind mapping, making percept graph } \\
\text { (what, who, when, where, how, and } \\
\text { why) about course content soft and hard } \\
\text { materials }\end{array}$ & $\begin{array}{l}\text { - Leaner-interface } \\
\text { interaction } \\
\text { - Learners-content } \\
\text { interaction } \\
\text { - Learner-support } \\
\text { interaction } \\
\text { - Learner-instructor } \\
\text { interaction }\end{array}$ \\
\hline $\begin{array}{c}\text { Acting- } \\
\text { engagement }\end{array}$ & $\begin{array}{l}\text { - Present } \\
\text { - Share }\end{array}$ & $\begin{array}{l}\text { Knowledge } \\
\text { generator }\end{array}$ & $\begin{array}{l}\text { Knowledge } \\
\text { mediator }\end{array}$ & $\begin{array}{l}\text { Face-to-face lectures, } \\
\text { teaching and learning } \\
\text { conference, lab-based } \\
\text { activities, role play, } \\
\text { brain storming, } \\
\text { collaborative teaching }\end{array}$ & $\begin{array}{c}\text { In-class-activities: Presentations, } \\
\text { asking questions, notation, compare, } \\
\text { experimental data interpretation, and lab } \\
\text { report write-up, group-based learning } \\
\text { activities (collaborative } \\
\text { learning) } \\
\text { well-structured problem solving }\end{array}$ & $\begin{array}{c}\text { - Learner-learner } \\
\text { interaction } \\
\text { - Learner-instructor } \\
\text { interaction }\end{array}$ \\
\hline $\begin{array}{l}\text { Reflecting- } \\
\text { engagement }\end{array}$ & $\begin{array}{l}\text { - Connect } \\
\text { - Elaborate }\end{array}$ & $\begin{array}{l}\text { Cognition } \\
\text { builder and } \\
\text { creator }\end{array}$ & $\begin{array}{l}\text { Cognition } \\
\text { activator, and } \\
\text { Cognition } \\
\text { Coach }\end{array}$ & $\begin{array}{l}\text { Cognitive-guided } \\
\text { instruction, } \\
\text { cognitive coaching, case } \\
\text { study, brain storming, } \\
\text { focus group technique, } \\
\text { triangulation teaching, } \\
\text { teaching and learning } \\
\text { conference }\end{array}$ & $\begin{array}{l}\text { In-class and out-of-class activities: } \\
\text { Data interpretation, } \\
\text { parallel problem solving, } \\
\text { report writing, } \\
\text { learn to graph and tabulate data, } \\
\text { case evaluation }\end{array}$ & $\begin{array}{l}\text { - Learner-learner } \\
\text { interaction } \\
\text { - Learner-instructor } \\
\text { interaction } \\
\text { - Learner-expert } \\
\text { interaction } \\
\text { - Learners-learners } \\
\text { interaction }\end{array}$ \\
\hline $\begin{array}{l}\text { Re-acting- } \\
\text { engagement }\end{array}$ & $\begin{array}{c}\text { - Model } \\
\text { - Transform }\end{array}$ & $\begin{array}{c}\text { Cognition } \\
\text { distributor and } \\
\text { manager }\end{array}$ & $\begin{array}{l}\text { Cognition } \\
\text { maintainer }\end{array}$ & $\begin{array}{c}\text { Games and simulation, } \\
\text { intelligent tutoring sys- } \\
\text { tems, } \\
\text { online debate, } \\
\text { what is the big idea } \\
\text { activities }\end{array}$ & $\begin{array}{l}\text { Out-of-class activities: } \\
\text { Prepare oral presentations, prepare } \\
\text { project report, solving other students' } \\
\text { problems, answering other students' } \\
\text { questions, adding new learning } \\
\text { materials to the course website, } \\
\text { evaluating other courses' e-materials } \\
\text { based on personal-made criteria }\end{array}$ & $\begin{array}{l}\text { - Learner-context } \\
\text { interaction }\end{array}$ \\
\hline
\end{tabular}




\subsubsection{Self-Study Skills Scale}

Approaches and Study Skills Inventory for Students (ASSIST) was used in this study to measure students' ability of deep learning and study skills. This scale was developed by [34]. It is consisting of four dimensions: Seeking Meaning; Relating Ideas; Use of Evidences; and Interest in Ideas.

ASSIST is self-reporting test consisting of 52 items. It depends on actual score of between 1 and 5 for each of the fifty two statements. Entering a score of " 5 " indicates that learners are a master of the skill or always practice the habit of deep learning while studying. Entering a score of " 1 " indicates that learners do not employ or never practice the habit of deep learning while studying. For the purpose and context of current research ASSIST was translated into Arabic Language. It was applied on a pilot sample of 14 graduate students to compute its reliability coefficient. A Cronbach's Alpha of 0.79 was estimated for the Arabic version of ASSIST. Permission to use the ASSIST was granted by the author.

\subsubsection{Achievement Test}

A final exam consisted of 50 MCQs was applied on both the control group and the experimental group at the end of the class. This test covers all the expected learning outcomes of the quantitative data analysis course. A Cronbach's Alpha of 0.81 was estimated for this test.

\section{Results}

\section{Testing Study Hypotheses}

Hypothesis 1: The presentation of the proposed immersive learning model would not lead to significant differences between the performance of the experimental group and the control group on self-study skills.

To test this hypothesis, the researcher computed descriptive statistics and conducted a t-test for independent samples analysis. Table 2 presents the findings of descriptive and inferential statistics for the performance of the experimental and the control group on the self-study skills scale.

Table 2 shows that the experimental group post-test mean score in self-study skills scale is higher than the mean score of the control group $(M=218.57$ and $M=146.67)$ respectively. There were higher variations existing in the control group $(S D=17.321)$ than in the experimental group $(S D=15.119)$.

Table 2 explains that there was a significant difference between the post-test score on self-study scale. This difference was in favor of the experimental group $(t, 22)=10.119 ; p=0.000)$. Also, Table 2 shows that the amount of variance in the dependent variable (self-study skills) that was accounted for by the independent variable (immersive learning model) is equal to $84 \%$ approximately. This finding explains that using the proposed immersive learning model through flipped classroom has a statistical and practical impact on developing selfstudy skills among graduate students assigned to the experimental group. Based on this finding, we can reject the first hypothesis.

Hypothesis 2: The presentation of the proposed immersive learning model would not lead to significant differences between the performance of the experimental group and the control group on the achievement test.

To test this hypothesis, the researcher computed descriptive statistics and conducted a t-test for independent samples analysis. Table 3 presents the findings of descriptive and inferential statistics for the performance of the experimental and the control group on the achievement test.

Table 2. Descriptive statistics and t-test for the between group difference in post-test on self-study skills scale.

\begin{tabular}{ccccccc}
\hline Group & Mean & $S D$ & t-value & df & $p$ & Effect size \\
\hline Experimental $(\mathrm{N}=14)$ & 218.57 & 15.119 & & & & \\
Control $(\mathrm{N}=10)$ & 146.67 & 17.321 & 10.52 & 22 & 0.000 & 0.841 \\
\hline
\end{tabular}

Table 3. The descriptive statistics and t-test for the between group difference in post-test on the achievement.

\begin{tabular}{|c|c|c|c|c|c|c|}
\hline Group & Mean & $S D$ & t-value & df & $p$ & Effect size \\
\hline Experimental $(\mathrm{N}=14)$ & 39.07 & 4.14 & \multirow[b]{2}{*}{2.70} & \multirow[b]{2}{*}{22} & \multirow[b]{2}{*}{0.013} & \multirow[b]{2}{*}{0.25} \\
\hline Control $(\mathrm{N}=10)$ & 35.40 & 1.27 & & & & \\
\hline
\end{tabular}


Table 3 shows that the experimental group post-test mean score in the achievement test is higher than the mean score of the control group ( $M=39.07$ and $M=35.40$ ) respectively. There were higher variations existing in the experimental group $(S D=4.14)$ than the control group $(S D=1.27)$.

Table 3 explains that there was a significant difference between the post-test score on the achievement test. This difference was in favor of the experimental group $(t, 22)=2.70 ; p=0.013)$. Also, Table 3 shows that the amount of variance in the dependent variable (achievement test) that was accounted for by the independent variable (immersive learning model) is equal to $25 \%$ approximately. This finding explains that using the proposed immersive learning model through flipped classroom has a statistical and practical impact on achievement among graduate students assigned to the experimental group. Based on this finding, we can reject the second hypothesis.

\section{Discussion}

Immersive learning design model presented in this study is consisting of four main phases and eight learning techniques. This model was effective on developing both self-study skills and achievement. There were statistically differences between the experimental and the control group in self-study skills and achievement in favor of the experimental group. All students in the experimental group scored higher than the theoretical average in self-study skills and achievement. These results could encourage the uses of the proposed model (ILD) in all educational settings.

Although, there is very few literature that applied flipped classroom, these findings is partly similar with the finding of [8]. The findings are also supported by [31] study. Students in the experimental groups were responsible for navigating and emerging ideas about course content and materials.

Collaborative discussion of students' generated-questions during the acting phase was found to be an effective tool to improve global understanding of course materials. More than three quarter of students in the experimental group explained that being able to discuss questions with other classmates was beneficial for learning and understanding. This finding is similar with [30] study. This finding is also supported by [32] study.

Moreover, discussion of students' generated-questions during the acting phase was found to be an efficient tool to improve students' confidence. All students in the experimental group got an equal chance to post or write at least three questions during face-to-face session. In the first two sessions some students were shy to stand in the front of other students. In the third face-to-face session they were able to feel confident while raising their questions. In the fourth session, the majority of students in the experimental group felt that knowing other students questions was beneficial for understanding and trusting on what they done during the pro-acting phase. This finding is similar with [29] study.

In conclusion, PARR model for Immersive Learning Design were effective in helping graduate students to move from content engagement to cognitive engagement. Based on these findings and the proposed model, the researcher believes that this model can open a new gate to increase the applications of flipped classroom through all kinds of virtual learning environments. In order for the institutions and programs of virtual and e-learning to find a solution for lack of trust in learning outcomes and believes, researchers interested in issues and polices of virtual and e-learning should work on the development of constructive learning models and strategies. Such models enhance the value of learning and increase the cognitive outputs of learning at the individual and mass levels.

\section{Limitations}

The present research has several important limitations. First, because this investigation is not true experimental research conducted on a small sample studying a statistical course, the findings have limited generalizability beyond the specific students, learning tasks, and situation examined in this investigation. Second, the nature of this quasi-experimental research and the nature of its dependent variables do not allow one to draw perfect causal conclusions concerning the effects of PARR model on students' achievements.

\section{Recommendations}

Based on the research findings, the following recommendations are suggested to improve the instructional and learning practices of Web-based, virtual learning, and flipped classrooms: 
1) Personnel in charge with virtual and e-learning need to build bridges of trust in the outcomes of virtual and e-learning thorough providing online learning with learning models and strategies such as the one developed in this research.

2) There exists a real need for examining the effect of using PARR model on learning other subject matters and other e-courses.

3) There exists a need for investigating the impact of using PARR model through flipped classroom on developing higher order thinking skills such as critical and creative thinking skills.

4) There exists a real need for replicating the present study on larger randomly selected samples.

5) A qualitative study is needed to explore the best practices of using PARR model with special needs students studying through flipped classroom.

6) Further research should address cognitive engagement and self-determined learning among undergraduate students.

7) There exists a need to train staff members who teach virtual and e-learning courses on the use of the proposed immersive learning design model.

8) There exists a need to design and develop school and university curricula with the goal of fostering acting and pro-acting engagement in order to facilitate reflective and re-acting engagement.

9) Finally, more studies should examine the impact of PARR model on professional development for faculty and staff members in higher education institutions.

\section{References}

[1] Brownm J.S. and Adler, R.P. (2008) Minds on Fire: Open Education, the Long Tail, and Learning 2.0. EDUCAUSE Review, 43, 16-32.

[2] Abdelaziz, H.A. (2013) From Physical Benchmarks to Mental Benchmarks: A Four Dimensions Dynamic Model to Assure the Quality of Instructional Activities in Electronic and Virtual Learning Environments. Turkish Online Journal of Distance Education, 14, 268-281.

[3] Abdelaziz, H.A. (2013) Avatar-Based Coaching: Using Virtual World to Develop Sales Skills and Learning Satisfaction among Business Secondary School Students. International Journal of Online Marketing, 3, 1-13. http://dx.doi.org/10.4018/ijom.2013010101

[4] Partnership for $21^{\text {st }}$ Century Skills (2013) The $21^{\text {st }}$ Learning Framework. http://www.p21.org/

[5] Serim, F. (2012) Digital Learning: Strengthening and Assessing $21^{\text {st }}$ Century Skills. Jossey-Bass, San Francisco.

[6] Chatti, M.A., Jarke, M. and Specht, M. (2010) The 3P Learning Model. Educational Technology \& Society, $13,74-85$.

[7] Sun, J.C. and Rueda, R. (2012) Situational Interest, Computer Self-Efficacy and Self-Regulation: Their Impact on Student Engagement in Distance Education. British Journal of Educational Technology, 43, 191-204. http://dx.doi.org/10.1111/j.1467-8535.2010.01157.x

[8] Bergmann, J. and Sams, A. (2012) Flip Your Classroom: Reach Every Student in Every Class Every Day. ISTE, Washington, DC.

[9] District Administration (2012) Kansas City Plots Next Steps. www.DistrictAdministration.com

[10] De Freitas, S., Mendez, G., Liarokapis, F., Magoulas, G. and Poulovassilis, A. (2010) Learning as Immersive Experiences: Using the Four-Dimensional Framework for Designing and Evaluating Immersive Learning Experiences in a Virtual World. British Journal of Educational Technology, 41, 69-85. http://dx.doi.org/10.1111/j.1467-8535.2009.01024.x

[11] Siemens, G. (2006) Knowing Knowledge. http://www.elearnspace.org/KnowingKnowledge_LowRes.pdf

[12] Chatti, M.A., Jarke, M. and Specht, A. (2009) PLEF: A Conceptual Framework for Mashup Personal Learning Environments. IEEE Technical Committee on Learning Technology (TCLT), 11(3). http://www.ieeetclt.org/issues/july2009/index.html\#_Toc239246014

[13] Carwile, J. (2007) A Constructivist Approach to Online Teaching and Learning. Inquiry, 12, 68-73.

[14] Kolb, D.A. (1984) Experiential Learning. Prentice Hall, Englewood Cliffs.

[15] Jonassen, D. (1999) Designing Constructivist Learning Environments. In: Reigeluth, C., Ed., Instructional Design Theories and Models: A New Paradigm of Instructional Theory, Volume II, Lawrence Earlbum Associate, Mahwah, 215-240.

[16] McCarthy, B. (2007) 4MAT Lessons. https://daretodifferentiate.wikispaces.com/file/view/4MAT.pdf

[17] Carwile, J. (2007) A Constructivist Approach to Online Teaching and Learning. 
http://www.vccaedu.org/inquiry/inquiry-spring-2007/i-12-Carwile.html

[18] Anderson, N. (1996) A Functional Theory of Cognition. Lawrence Erlbaum Associates, Mahwah.

[19] Collins, A. (1988) Cognitive Apprenticeship and Instructional Technology: Technology Report. BBN Labs, Inc., Cambridge. (ERIC Document Reproduction No. ED 331 465)

[20] Fredricks, J.A., Blumenfeld, P. and Paris, A. (2005) School Engagement. In: Moore, K.A. and Lippman, L., Eds., What Do Children Need to Flourish? Conceptualizing and Measuring Indicators of Positive Development, Springer, New York, 305-321.

[21] Gresalfi, M. and Barab, S. (2011) Learning for a Reason: Supporting Forms of Engagement by Designing Tasks and Orchestrating Environments. Theory into Practice, 50, 300-310. http://dx.doi.org/10.1080/00405841.2011.607391

[22] Richardson, J.C. and Newby, T. (2006) The Role of Students' Cognitive Engagement in Online Learning. American Journal of Distance Education, 20, 23-37. http://dx.doi.org/10.1207/s15389286ajde2001_3

[23] Reeve, J. (2006) Teachers as Facilitators: What Autonomy-Supportive Teachers Do and Why Their Students Benefit. Elementary School Journal, 106, 225-236. http://dx.doi.org/10.1086/501484

[24] Harlow, L., Debacker, T. and Crowson, H. (2011) Need for Closure, Achievement Goals, and Cognitive Engagement in High School Students. The Journal of Educational Research (TJER), 104, 110-119. http://dx.doi.org/10.1080/00220670903567406

[25] Alonso, F., Lopez, G., Manrique, D. and Vines, J. (2008) Learning Objects, Learning Objectives and Learning Design. Innovations in Education and Teaching International, 45, 389-400. http://dx.doi.org/10.1080/14703290802377265

[26] Schulman, L.S. (2002) Making Differences: A Table of Learning. Change, 34, 36-44. http://dx.doi.org/10.1080/00091380209605567

[27] Rotgans, J. and Schmidt, H. (2011) Cognitive Engagement in the Problem-Based Learning Classroom. Advances in Health Sciences Education, 16, 455-479. http://dx.doi.org/10.1007/s10459-011-9272-9

[28] Arnone, M., Small, R., McKenna, H. and Chauncey, S. (2011) Curiosity, Interest and Engagement in TechnologyPervasive Learning Environments: A New Research Agenda. Educational Technology Research and Development, 59, 181-198. http://dx.doi.org/10.1007/s11423-011-9190-9

[29] Bates, R. and Khasawneh, S. (2007) Self-Efficacy and College Students’ Perceptions and Use of Online Learning Systems. Computers in Human Behavior, 23, 175-191. http://dx.doi.org/10.1016/j.chb.2004.04.004

[30] Quinton, S. and Smallbone, T. (2010) Feeding Forward: Using Feedback to Promote Student Reflection and LearningA Teaching Model. Innovations in Education and Teaching International, 47, 125-135. http://dx.doi.org/10.1080/14703290903525911

[31] Olsen, D., Bekken, B.M., McConnell, K.D. and Walter, C.T. (2011) Teaching for Change: Learning Partnerships and Epistemological Growth. The Journal of General Education, 60, 139-171. http://dx.doi.org/10.1353/jge.2011.0017

[32] Moon, J.A. (2002) Learning Journals: A Handbook for Academics, Students and Professional Development. Kogan Page, London.

[33] Magolda, M.B. (2000) Creating Context for Learning and Self-Authorship: Constructive Development Pedagogy. Vanderbilt University Press, Nashville.

[34] Webster, R. (2002) Learning Styles and Design: The Use of ASSIST for Reflection and Assessment, in Quality Conversations. Proceedings of the 25th HERDSA Annual Conference, Perth, 7-10 July 2002, 713. 
Scientific Research Publishing (SCIRP) is one of the largest Open Access journal publishers. It is currently publishing more than 200 open access, online, peer-reviewed journals covering a wide range of academic disciplines. SCIRP serves the worldwide academic communities and contributes to the progress and application of science with its publication.

Other selected journals from SCIRP are listed as below. Submit your manuscript to us via either submit@scirp.org or Online Submission Portal.
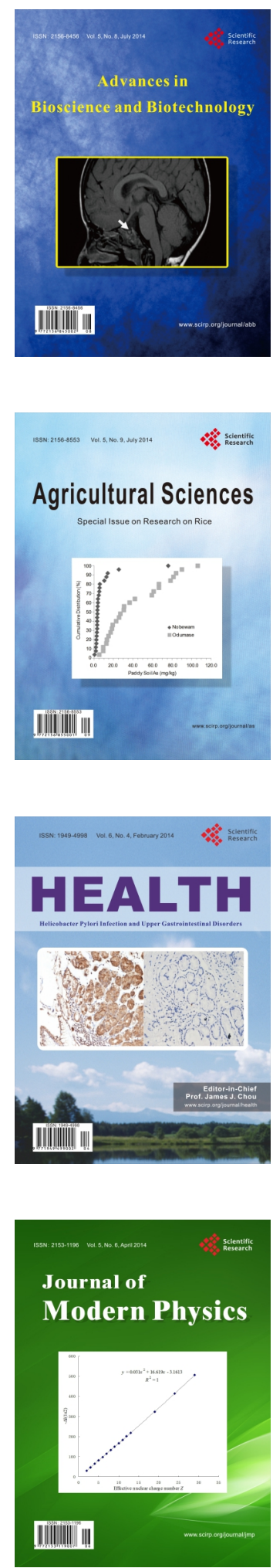
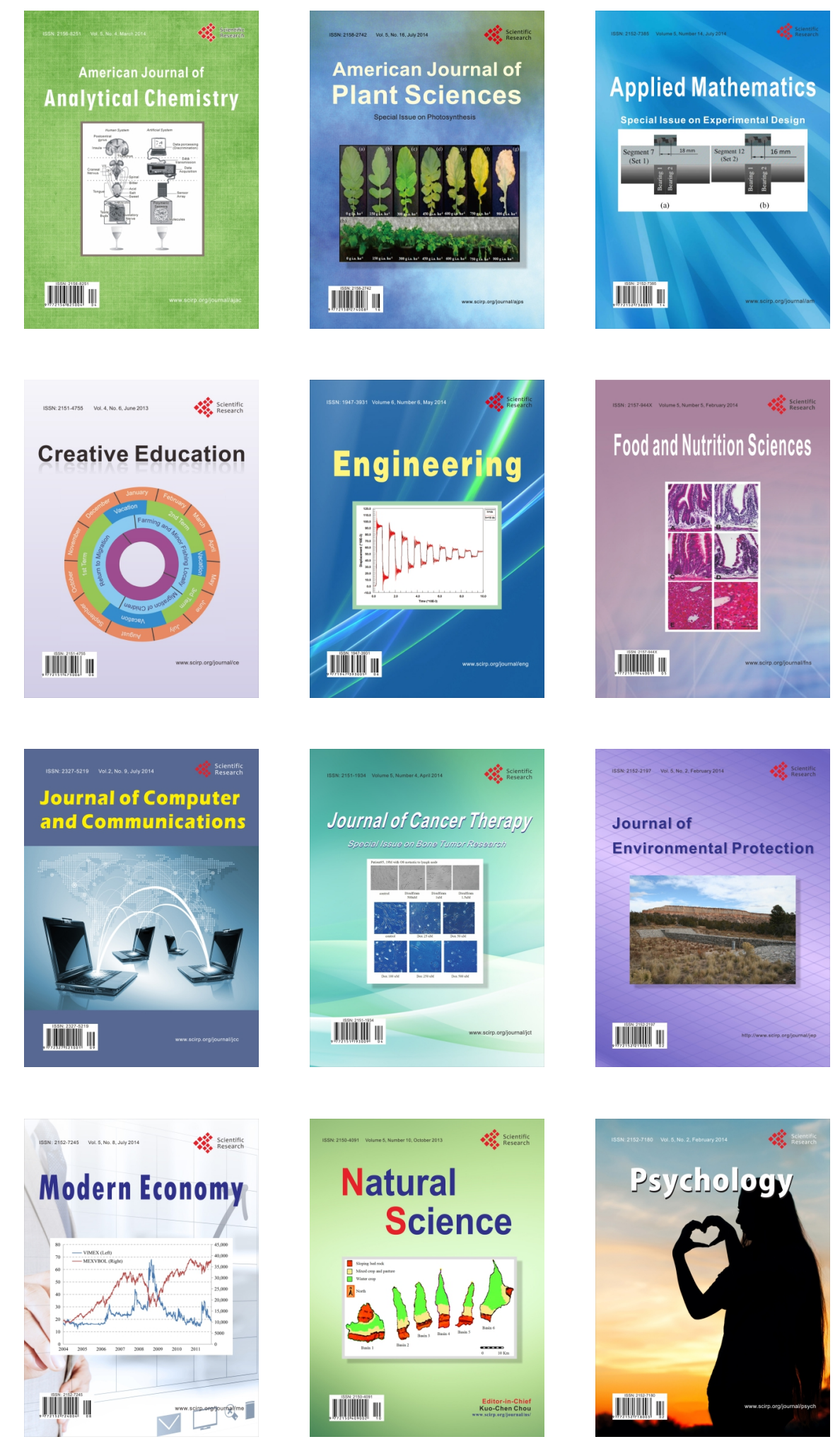